\title{
INFLUENCE OF SOME POTASSIUM HUMATE APPLICATION METHODS AND MINERAL FERTILIZATION OF NITROGEN AND PHOSPHORUS ON SOYBEAN YIELD AND QUALITY
}

\author{
K. E. M. Nassar, Hayam A. EL-Shaboury and Amany E. EL-Sonbaty \\ Plant Nutrition and Soil Fertility Res. Dep.; Soils, Water and Environment Res. Inst.; Agric. Res. \\ Centre, Giza, Egypt.
}

Received: May 17, 2021

Accepted: May 22, 2021

\begin{abstract}
Two field experiments were conducted on Gadila village, Mansoura city, Dakahlia Governorate during the two successive summer seasons of 2017 and 2018 as sake of studying the impact of some methods of potassium humate $(\mathrm{KH})$ application along with nine mixtures of NP fertilizers on soybean plants . split plot design was used where KH application methods and NP mixtures were put in the main and sub plots, respectively. Addition of KH generally had enhancing impacts on soybean growth , seed and stalk yields as well as improved seed nutritive and biochemical contents. Foliar spraying of $\mathrm{KH}$ achieved the maximum values followed by seed coating and control in a descending order. Soil application of $(100 \% N+100 \% P)$ mixture attained the best results for all aforementioned characteristics with no significant difference between it and $(75 \% \mathrm{~N}+100 \% \mathrm{P})$ mixture. Foliar spraying of soybean plants with $2 \% \mathrm{KH}$ solution $(10 \% \mathrm{~K} 2 \mathrm{O})$ in a volume of $200 \mathrm{~L}$ fed -1 at 30 and 45 days after sowing and soil application of $(75 \% N+100 \% P)$ of the recommended doses, in a dual treatment achieved the superior impacts and recorded the highest values of plant growth criteria, productivity as well as improved seed quality characteristics and saved $25 \%$ of $\mathrm{N}$ requirement for soybean plants.
\end{abstract}

Key words: Potassium humate; NP fertilizers; soybean; seed coating; foliar spraying.

\section{INTRODUCTION}

Soybean (Glycine max L.) is extensively planted in Egypt and many countries under different environments with a short duration around the world and has high nutritional value, with multiple uses as food and industrial products. It also contains high amounts of minerals, salts, vitamins (thiamine and riboflavin), protein (an average of $36-43$ $\%)$, oil (19- $20 \%$ ) and amino acid lysine $(5 \%)$, which is usually deficient in many cereal crops (Kravchenko et al., 2013 and Yadav et al., 2013). Also, there are many other products such as milk and flour can be extracted from it. Growing soybean can maintain the soil fertility through increasing fixation of atmospheric $N\left(125-150 \mathrm{~kg} \mathrm{~N} \mathrm{ha}^{-1}\right)$ and this may reduce nitrogen requirements for plants (Yadav et al., 2013) .
Humate substances can directly or indirectly affect the physiological processes of plant growth by promoting the uptake of both macro- and micronutrients and growth regulators, increasing the microorganisms population and activity as hormone like substances (Verlindern et al., 2009). Yet, humate substances enhance the water retention, the seed filling intensity. The chelating agent through active groups also hold macronutrients and forming organometallic complexes which are considered as a storehouse, or more mobile or available to be taken up by plant and in turn reflected positively on development seed and straw yields and their attributes (Rafla, 2012). Yet, (EIGhamry et al., 2009; El- Bassiony et al., 2010 and Nassar and Abd El-Rahman, 
2015) reported that all morphological characteristics, yield components as well as contents of chlorophyll and nutrients were significantly increased by foliar application of humate substances. Nassar and Abd El-Rahman (2015) also stated that soil additions of both compost and K-humate increased the quantities of both wheat grain and straw yields, improved their qualities and raised the use efficiency of the added $\mathrm{N}$ fertilizer. Habashy and Aly (2005) also observed that soaking the wheat grains in K-humate solution had a superior effect on germination characteristics and emergence.

Mineral fertilization is essential for plant growth, development and yield productivity. (El-Bassiony et al., 2010) reported that applying the adequate quantities of balanced NPK mineral fertilizers is the first requirement for achieving optimum yield and doing so will result in soybean of acceptable quality. Nitrogen is essential for synthesis of chlorophyll, enzymes and proteins. Phosphors is essential for root growth, phosphoproteins, phospholipids and ATP \& ADP formation. It may be a critical constraint of legumes under low nutrient environments because there is substantial need for $P$ in the $\mathbf{N}_{2}$ fixation processes (Tsvetkova and Georgiev, 2007) because of the involvement of $P$ in the high rates of energy transfer that must take place in the nodule. In addition, phosphorus has an enhancing impact on plant growth and biological yield through its importance as energy storage and transfer necessary for metabolic processes (Nassar and Ismail, 1999). Phosphorus cause early ripening in plants, decreasing grain moisture and improving crop quality (Malakooti, 2000). It also raises the efficiency of plants to photosynthesis, enhances the activity of rhizobia and increases the number of branches and pods / plant. Consequently, it produces a greater total yield of soybean.

Therefore, the aim targets of the current investigation are increasing soybean seed and stalk yields and improving seed quality through the addition of K-humate along with different mixtures of $\mathrm{N}$-and $\mathrm{P}$-mineral fertilizers as sake of rationalization the use of mineral fertilizers. Evaluation the impact of two different methods of K-humate application was also taken into consideration as sake of selecting the best method which achieve the highest yield with better quality.

\section{MATERIALS AND METHODS}

Two field experiments were carried out at a private farm on Gadila village (5 km north-west to Mansoura), Mansoura city, Dakahlia Governorate, Egypt during the two successive summer seasons of 2017 and 2018. Mechanical and chemical properties of the soils under investigation as well as their nutritive contents are presented in Table $1(a, b$ and $\mathrm{c}$ ).

The mechanical and chemical properties of the soils under investigation were determined according to USDA (2014) and (Jackson, 1973), respectively. However, soil nutritive contents were determined according to (Chapman and Pratt, 1978) .

Soybean (Glycine max L.) seeds variety Giza 111 were purchased from Leguminous Crops Res. Depart., ARC and were planted on 7 and $\mathbf{1 0}$ May for the $1^{\text {st }}$ and $2^{\text {nd }}$ seasons, respectively, in rows $3.5 \mathrm{~m}$ a length, $50 \mathrm{~cm}$ a part with an intrarow spacing of $20 \mathrm{~cm}$ (plot size $=3 \times 3.5 \mathrm{~m}$ ). Potassium hamate solution containing 10 $\% \mathrm{~K}_{2} \mathrm{O}$ was obtained from Plant Nutrition and Soil Fertility Res. Depart., ARC. 
Table 1: Mechanical and chemical analyses as well as available nutritive contents of the soils under investigation (surface layers, at the depth of $0-30 \mathrm{~cm}$ ), before planting for the two studied seasons.

a) Mechanical analysis:

\begin{tabular}{|c|c|c|c|c|c|}
\hline \multirow{2}{*}{ Season } & \multicolumn{4}{|c|}{ Particle size distribution (\%) } & \multirow{2}{*}{ Texture class } \\
\cline { 2 - 5 } & Coarse sand & fine sand & Silt & Clay & \\
\hline 1 st & 8.32 & 19.67 & 36.74 & 35.27 & Clay loam \\
\hline $2^{\text {nd }}$ & 7.46 & 18.32 & 37.50 & 36.72 & Clay loam \\
\hline
\end{tabular}

b) Chemical analysis :

\begin{tabular}{|c|c|c|c|c|c|c|c|c|c|c|c|c|}
\hline \multirow{3}{*}{ Season } & \multirow{3}{*}{$\begin{array}{c}\mathrm{CaCO}_{3} \\
(\%)\end{array}$} & \multirow{3}{*}{$\begin{array}{c}\mathrm{EC} \\
\left.(\mathrm{dSm})^{-1}\right) \\
(1: 5)\end{array}$} & \multirow{3}{*}{$\begin{array}{c}\text { PH } \\
(1: 2.5)\end{array}$} & \multirow{3}{*}{$\begin{array}{l}\text { O.M } \\
(\%)\end{array}$} & \multicolumn{8}{|c|}{ Soluble ions meq. L-1 (1:5 soil : water extract) } \\
\hline & & & & & \multicolumn{4}{|c|}{ Cations } & \multicolumn{4}{|c|}{ Anions } \\
\hline & & & & & $\mathrm{Na}$ & K+ & $\mathrm{Ca}++$ & $M g++$ & CO3- & HCO3- & $\mathrm{Cl}-$ & so4-- \\
\hline 1 st & 3.91 & 0.86 & 7.90 & 1.47 & 2.87 & 0.21 & 3.90 & 1.58 & 0.00 & 1.02 & 2.72 & 4.82 \\
\hline $2^{\text {nd }}$ & 3.64 & 0.89 & 7.86 & 1.45 & 2.96 & 0.27 & 3.97 & $\overline{1.66}$ & 0.00 & 1.09 & 2.78 & 4.99 \\
\hline
\end{tabular}

c) Available nutritive contents $\left(\mathrm{mg} \mathrm{kg}^{-1}\right)$ :

\begin{tabular}{|c|c|c|c|c|c|c|}
\hline \multirow{2}{*}{ Season } & \multicolumn{3}{|c|}{ Macro } & \multicolumn{3}{c|}{ Micro } \\
\cline { 2 - 7 } & $\mathrm{N}$ & $\mathrm{P}$ & $\mathrm{K}$ & Fe & Mn & Zn \\
\hline $1^{\text {st }}$ & 54.13 & 4.79 & 177 & 2.98 & 1.35 & 0.65 \\
\hline $2^{\text {nd }}$ & 52.64 & 4.62 & 179 & 2.56 & 1.22 & 0.62 \\
\hline
\end{tabular}

Each experiment included twenty seven treatments which were the combinations of three treatments of potassium humate $(\mathrm{KH})$ and nine mixtures of $\mathrm{N}$ - and $\mathrm{P}$ - mineral fertilizers. So, the layout of each experiment was split plot design with three replications. Each replicate was divided into three main plots representing the different treatments of potassium humate as the following:

A - Without the addition of K- humate (control).

B - Seed coating with $2 \% \mathrm{~K}$ - humate, in the presence of adhesive agent (gum arabic), directly before sowing.

C - Foliar spraying of soybean plants with $2 \% \mathrm{KH}$ solution $\left(10 \% \mathrm{~K}_{2} \mathrm{O}\right)$ in a volume of $200 \mathrm{~L} \mathrm{fed}^{-1}$, at 30 and 45 days after sowing.

Each main plot was randomly subdivided into nine sub plots representing the different mixtures of $\mathrm{N}$ and $\mathrm{P}$-mineral fertilizers as the following: 1. $100 \% N+100 \% P$.
2. $100 \% \mathrm{~N}+75 \% \mathrm{P}$.

3. $100 \% \mathrm{~N}+50 \% P$.

4. $75 \% N+100 \% P$.

5. $75 \% \mathrm{~N}+75 \% \mathrm{P}$.

6. $75 \% N+50 \% P$.

7. $50 \% \mathrm{~N}+100 \% \mathrm{P}$.

8. $50 \% \mathrm{~N}+75 \% \mathrm{P}$.

9. $50 \% \mathrm{~N}+50 \% \mathrm{P}$.

Doses of $\mathrm{N}$ - and $\mathrm{P}$ - mineral fertilization recommended for soybean plant are 20 $\mathrm{kg} \mathrm{N}$ fed $^{-1}$ and $22.5 \mathrm{~kg} \mathrm{P}_{2} \mathrm{O}_{5}$ fed $^{-1}$. However, the abovementioned percentages represent $100 \%$ of the recommended doses, mentioned before.

$\mathrm{N}$ - and $\mathrm{P}$ - mineral fertilizers were applied in the forms of urea $(46.5 \% \mathrm{~N})$ and single superphosphate $\left(15.5 \% \mathrm{P}_{2} \mathrm{O}_{5}\right)$, respectively. Calcium superphosphate was broadcasted during the soil preparation, whilst, urea was applied in two equal doses before the first and second irrigations. The other usual agronomic processes of soybean were practiced. 
At 65 days age, a sample of 10 plants from each plot was randomly chosen to calculate fresh and dry weights of the whole plants. Yet, a sample of the fourth leaves was taken to determine Chlorophyll a , b and carotenoids according to (Gavrilenko and Zigalova, 2003).

At harvest (120 days after sowing), a sample of 20 plants from each plot was harvested. Then, number of branches and pods plant ${ }^{-1}$, seed yield plant $^{-1}$ as well as 100 seed weight were recorded. Seed and stalk yields were recorded on plot basis. Then, they were estimated as ton fed ${ }^{-1}$ (fed. $=0.42$ hectare). $\mathbf{N}, \mathrm{P}$ and K percentages of soybean seed were determined in wet digested extract using the methods described by Mertens (2005 $a$ and $b$ ). Values of $N, P$ and $K$ contents in seed were also estimated as $\mathrm{Kg} \mathrm{fed}^{-1}$. Seed crude protein $\left(\mathrm{Kg} \mathrm{fed}{ }^{-1}\right)$ was determined by multiplying the values of $\mathbf{N}$ $\left(\mathrm{Kg} \mathrm{fed}^{-1}\right)$ in seed by 6.25 , according to (A.O.A.C., 2000). Total carbohydrate, dietary fiber and oil percentages were determined according to (Shumaila and Safdar, 2009 ; Rai and Mudgal, 1988 and A.O.A.C., 2000), respectively. Then, total carbohydrate, dietary fiber and oil contents in $\mathrm{Kg} \mathrm{fed}^{-1}$ were also estimated.

Combined analyses for the two growing seasons were statistically analyzed according to (Gomez and Gomez, 1984). The significant differences among the means of treatments were tested using the least significant difference (L.S.D.) at the $5 \%$ level of probability.

\section{RESULTS AND DISCUSSION}

Data presented in Tables (2, 3 and 4) represent the average of the values attained in 2017 and 2018 summer seasons. The current investigation aimed to raise the productivity of soybean and improve seed quality through the addition of potassium humate in two methods (seed coating and foliar spraying) along with different mixtures of $\mathrm{N}$ - and P-mineral fertilizers as well as their possible combinations on some growth criteria and yield components of soybean. Yet, their impacts on the seed contents of some nutrients and biochemical constituents were also taken into consideration.

\section{Effect of methods of potassium humate application :}

Data obtained in Table (2) revealed that the addition of potassium humate (KH) significantly increased the concentrations of photosynthetic pigments and weight of whole plant at 65 days age. At harvest, seed and stalk yields as well as yield components (No. of branches and pods / plant, 100 seed weight and yield / plant) gave trends similar the trend mentioned before. Moreover, seed nutritive and biochemical contents were also significantly enhanced by $\mathrm{KH}$ application. The enhancements of plant growth criteria, yield components as well as seed nutritive and biochemical contents were mainly due to foliar spraying with $\mathrm{KH}$ rather than seed coating and control in a descending order. The beneficial impact of $\mathrm{KH}$ on the concentrations of photosynthetic pigments, plant growth, seed and stalk yields, contents of seed nutrients and biochemical constituents could be explained on the basis of that humic substances can directly or indirectly affect the physiological processes of plant growth by promoting the uptake of macro-and micronutrients and affecting the biochemical substances, carrying nutrients and growth regulators and acting as hormone like substances (Verlindern et al., 2009). On the other hand, (Wang et al., 2015; Ismail et al., 2017 and Dawood et al., 2019) also attributed the enhancing impact of $\mathrm{KH}$ to the beneficial functions of potassium on osmoregulation, photosynthesis, transpiration, open and 


\begin{tabular}{|c|c|c|c|c|c|c|}
\hline \multirow{13}{*}{ 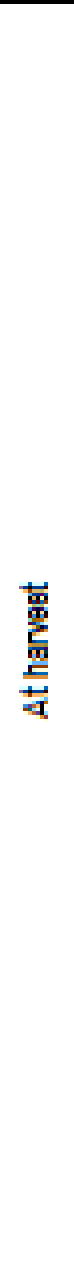 } & \multirow{7}{*}{ 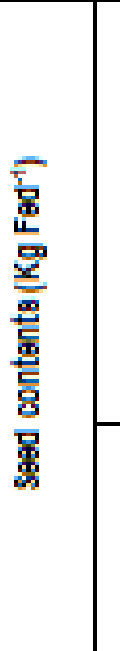 } & $\overline{\bar{z}}$ & $\frac{\underline{m a}}{\bar{N}}$ & 5 & 票 & 9 \\
\hline & & 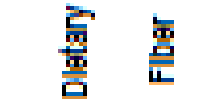 & 娄 & 覃 & $E$ & 虽 \\
\hline & & 焉 镸要 & 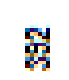 & 荨 & 洋 & 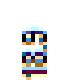 \\
\hline & & 爱毫 & $\overline{\bar{q}}$ & 唱 & g & g \\
\hline & & $\simeq$ & 梠 & पू & 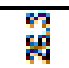 & $\frac{9}{8}$ \\
\hline & & $a$ & 뎔 & 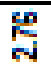 & 뎝 & $\bar{E}$ \\
\hline & & $z$ & 엽 & 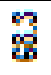 & 畣 & 9 \\
\hline & \multirow{2}{*}{ 蛐 } & 膪 & 9 & 简 & g & Бㅁ \\
\hline & & 墨 & 둰 & $\bar{F}$ & 算 & $\overline{5}$ \\
\hline & \multirow{4}{*}{ 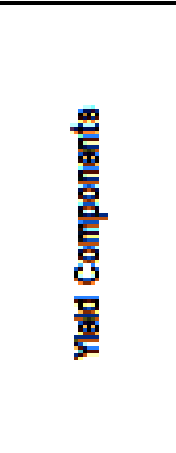 } & 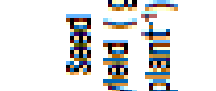 & 岛 & 론 & 量 & $\mathrm{g}$ \\
\hline & & 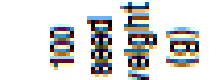 & $\bar{I}$ & g & $\stackrel{B}{E}$ & 돔 \\
\hline & & 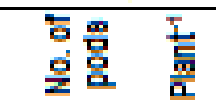 & $\stackrel{p}{p}$ & 9 & 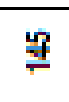 & 蒋 \\
\hline & & 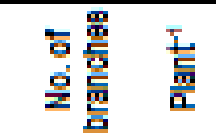 & 웝 & $\overline{3}$ & 噌 & 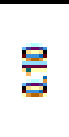 \\
\hline \multirow{6}{*}{ 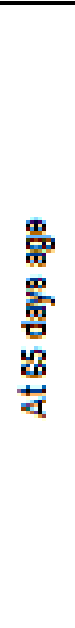 } & \multirow{2}{*}{ 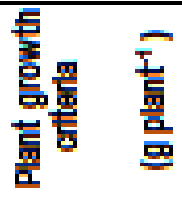 } & 窝 高 & 筩 & $\overline{5}$ & 9 & 혐 \\
\hline & & 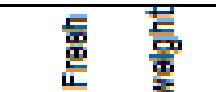 & s & 舜 & 点 & 역 \\
\hline & \multirow{4}{*}{ 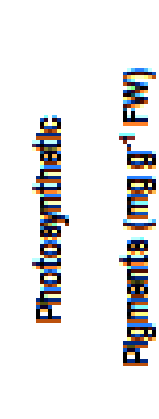 } & $\begin{array}{l}\text { 豆 } \\
\text { 謇 }\end{array}$ & 总 & 梠 & 嗰 & g \\
\hline & & 岳曋 & 峲 & $\underline{g}$ & 喜 & 璐 \\
\hline & & $\overline{\bar{z}}$ & 罗 & 繁 & 辅 & 窎 \\
\hline & & $\frac{2}{\frac{3}{5}}$ & 雪 & 害 & 뎜 & 害 \\
\hline & \multicolumn{2}{|c|}{ 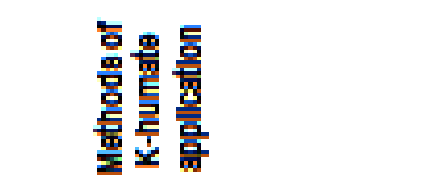 } & 誊 & 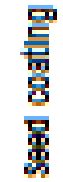 & $\begin{array}{l}\text { 訔 } \\
\text { 言 } \\
\text { 产 } \\
\text { 产 }\end{array}$ & $\begin{array}{l}\text { 悹 } \\
\text { 总 } \\
\text { 留 }\end{array}$ \\
\hline
\end{tabular}


closure of stomata, protein synthesis and translating of assimilates into sink organs.

The superiority impact of $\mathrm{KH}$ foliar spraying method compared to $\mathrm{KH}$ coating one and control may be due to stimulating of leaf area and water retention, impacting as an activator for physiological respiration, photosynthesis, protein synthesis, water and nutrient uptake, cationic exchange capacity, enzyme activities and antioxidant metabolism. As a result, photosynthetic materials help in the fill grains that can increase yield. In this respect, (Afifi et al., 2010) on Faba bean and (Kaya, 2005) on common bean also stated that humic acid molecules are small which allows them to reach the plant plasma, increases the permeability of plant cellular membranes and enhances the uptake of nutrients .Yet, (Dorneanu et al., 2008) reported that foliar spraying of humate substances (HS) enhance the penetration of nutritive ions in leaves, stimulate the formation of some physiological active metabolic compounds and enlarge the capacity of plants for root absorption. As increasing nutrients uptake especially $\mathrm{N}$ and $\mathrm{K}$ which increase number of chloroplast per cell as well as photosynthetic efficiency and increase sugar content (Chen and Avaid, 1990). Obtained findings are in confirmity by those of (El-Bassiony et al., 2010) on snap bean , (Khan et al., 2012) on peas, (Shafeek et al., 2013) on broad bean (Nassar and Abd EL-Rahman, 2015) on wheat, (Wang et al., 2015) on soybean, (Ismail et al., 2017) on Pea , (Fuda, 2017 ; Dawood et al., 2019) on faba bean who reported that all morphological characteristics, yield components as well as contents of chlorophyll, nutrients and biochemical constituents were significantly increased by foliar spraying of humate substances. Similar results were also attained by (Yousif et al., 2019) where they stated that foliar spraying of broad bean plants with humic acid $(18 \mathrm{~m}$ $\mathrm{L}-1$ ) is very beneficial to the crop growth, yield and nutrient content (N. P. and K\%).

I. Effect of different mixtures of $\mathrm{N}$ - and P- mineral fertilizers:

As shown in Table (3), plant growth parameters, yield components as well as seed nutritive contents and biochemical constituents were progressively descended by decreasing the levels of $\mathbf{N}$ and / or $\mathbf{P}$ in the tested mixtures. In this respect, the addition of full recommend doses for both $\mathrm{N}$ - and $\mathrm{P}$ - fertilizers namely the treatment of $(100 \% N+100 \%$ $\mathrm{P})$ achieved the maximum values for all abovementioned parameters followed by the treatment of $(75 \% \mathrm{~N}+100 \%$ P) but there was no significant difference between the aforementioned two treatments. on the other hand, the least values for the growth, yield as well as seed nutritive and biochemical contents were recorded when the addition of half amounts of the recommended doses for both $\mathrm{N}$-and P-fertilizers namely the treatment of $(50 \% N+50 \% P)$.

Date attained herein clearly show the following important topics :

1- Application of mineral fertilizers is essential for plant growth, development as well as yield productivity and quality. (ELBassiouny et al., 2010) also reported that applying of adequate quantities of balanced NPK mineral fertilizers is the first requirement for achieving optimum yield and doing so will result in soybean for acceptable quality.

2- As soybean is a leguminous crop and fixes $N$ in large amounts, it ables to compensate a part of mineral $\mathbf{N}$ to cover $\mathrm{N}$ requirement

3- Characters of soybean growth, yield, nutritive and biochemical constituents tested herein were largely affected by the diminution of P-levels in the 


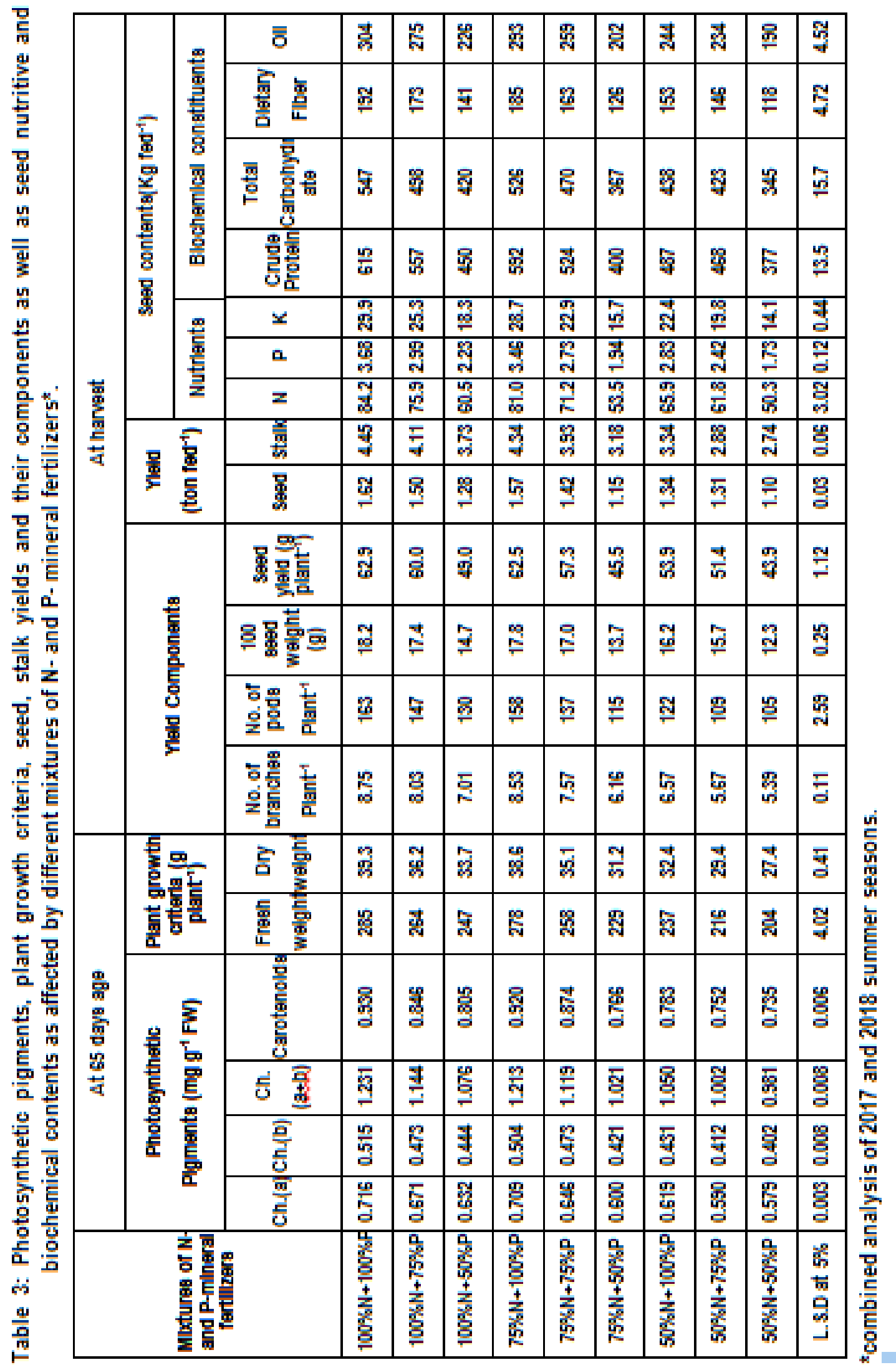


mixtures used under the present study. this might be due to the depression of available phosphorus contents in the experimental soils $(4.79$ and 4.62 $\mathrm{mg} / \mathrm{kg}$, in the 1st and 2nd seasons, respectively), Table 1 -b and/or a substantial need for $P$ in the $N 2$ fixation process (Tsvetkova and Georgiev, 2007) because of the involvement of $P$ in the high rates of energy transfer that must take place in the nodule. In addition, phosphorus has an enhancing impact on plant growth and transfer necessary for metabolic processes (Nassar and Ismail, 1999). Phosphorus also causes early ripening in plants, decreases grain moisture , improves crop quality, raises the efficiency of plants to photosynthesis, enhances the activity of rhizobia and increases the number of branches and pods / plant . Consequently, it produces a greater total yield of soybean (Malakooti, 2000).

\section{Interaction effect of application methods of potassium humate and different mixtures of $\mathrm{N}$ - and $\mathrm{P}$ - mineral fertilizers :}

Date presented in Table (4) clearly show that the addition of potassium humate raises the efficiency of mineral fertilizers adding to the soil compared with the control treatment (untreated). It was reflected on all studied characteristics (photosynthetic pigments, plant growth, productivity as well as seed quality characters namely nutritive and biochemical contents. In this concern , application of $\mathrm{KH}$ and mineral fertilizers simultaneously achieved values higher than those recorded when their application singly. The highest values were observed when foliar spraying of $\mathrm{KH}$ together with the addition of full recommended doses of NP fertilizers i.e. $(100 \% N+100 \%$ P) followed by the dual treatment of $\mathrm{KH}$ foliar spraying and $(75 \% N+100 \% P)$ but there was no significant difference between the abovementioned two treatments .

\section{CONCLUSIONS}

Foliar spraying the soybean plants with $2 \% \mathrm{~K}$-humate solution $\left(10 \% \mathrm{~K}_{2} \mathrm{O}\right)$ at 30 and 45 days after sowing and soil application of $(75 \% \mathrm{~N}+100 \% \mathrm{P})$ of the recommended doses, in a dual treatment achieved the superior impact and recorded the highest values of photosynthetic pigments, plant growth criteria, seed and stalk yields and improved seed quality characteristics namely seed nutritive and biochemical contents . In addition, this treatment saved $25 \%$ of the $\mathrm{N}$ recommended dose. 


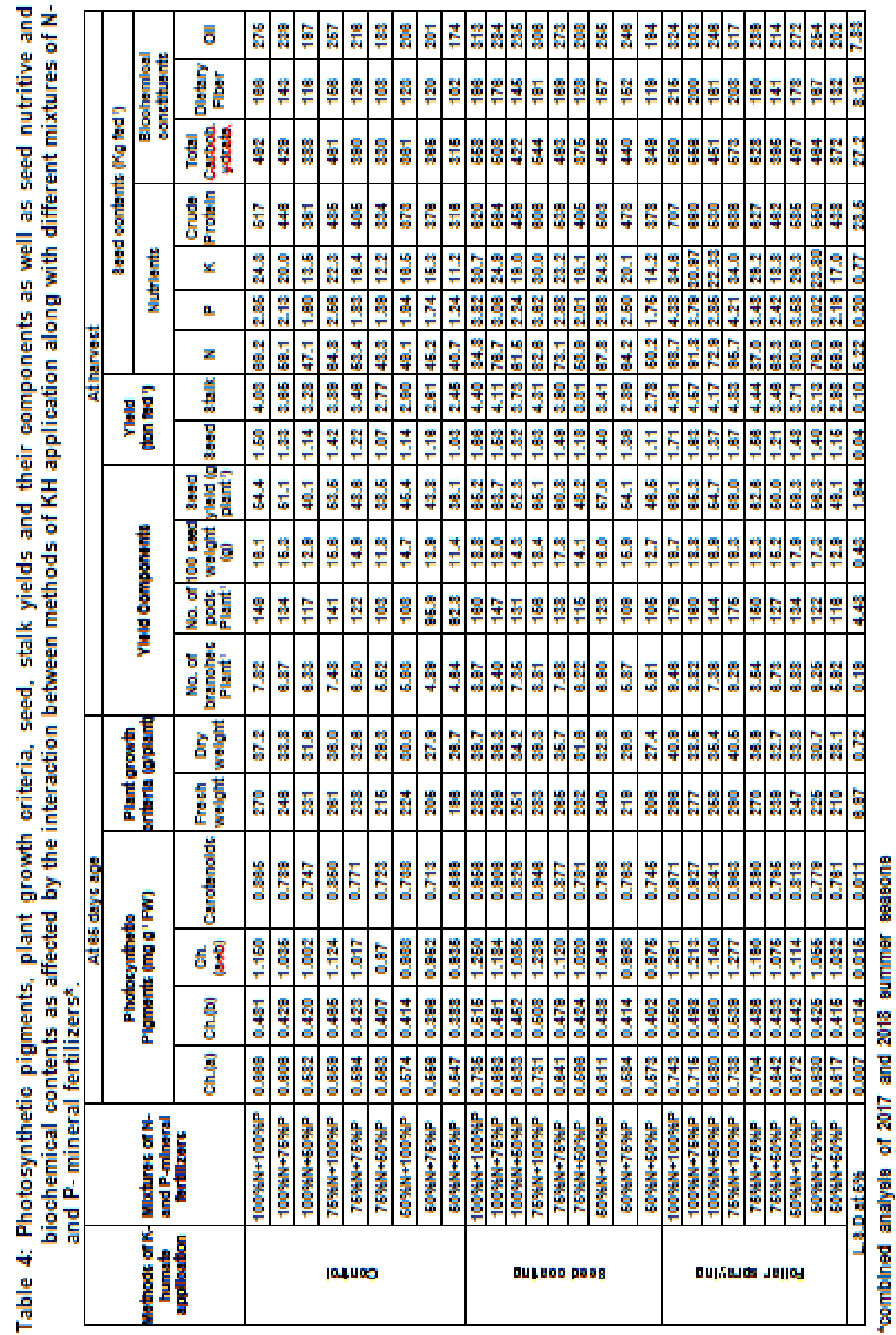




\section{REFERENCES}

Afifi, M. H. M., M. F. Mohamed and S. H. A. Shaaban (2010). Yield and nutrient uptake of some Faba bean varieties grown in newly cultivated soil as affected by foliar application of humic acid . Journal of Plant Production 1 (1): 77-85.

A.O.A.C., (2000). Association of Official Analytical Chemists, 17th ed. of A.O.A.C. international published by A.O.A.C. international Maryland, U.S.A., 1250 pp.

Chapman, H. O. and P. E. Pratt (1978). Methods of Analysis for Soils, Plants and Waters. Univ. California Div. Agric. Sci.

Chen, Y. and T. Aviad (1990). Effects of humic substances on plant growth. In: Humic Substances in Soil and Crop Science: Selected Readings, eds. P. Mac Carthy, C. E. Clapp, R. L. Malcolm, and P. R. Bloom, pp. 161186. Madison, WI: SSSA and ASA.

Dawood, M.G., Y.R. Abdel-Baky, , M. E. El-Awadi and G.S. Bakhoum (2019). Enhancement quality and quantity of Faba bean plants grown under sandy soil conditions by nicotinamide and/or humic acid application. Bulletin of the National Research Centre 43:28.

Dorneanu, A.D. , M. E. Dorneanu, C. Preda, L. Anton and L. Oprica (2008). Fertilization with liquid humic fertilizers, procedure of high efficiency in improving plant nutrition along the growing season. Proc. $17^{\text {th }}$ Intern. Symp. of CIEC, 24-27 Nov. Micronutrient Project, Cairo, Egypt, pp. 259-264.

El-Bassiony, A. M., Fawzy, Z. F., Abd ElBaky, M. M. H. \& Mahmoud, A. R. (2010). Response of snap bean plants to mineral fertilizers and humic acid application. Research Journal of Agriculture and Biological Sciences, 6(2): 169-175.

El-Ghamry, A.M., K.M. Abd El-Hai and K.M. Ghoneem (2009). Amino and humic acids promote growth, yield and disease resistance of Faba bean cultivated in clayey soil. Australian Journal of Basic and Applied Sciences, 3(2):731-739.

Fouda, K.F. (2017). Effect of Phosphorus level and some growth regulators on productivity of Faba bean (Vicia faba L.). Egypt Journal Soil Sci., 57 (1): 73 87.

Gavrilenko, V. F. and T. V. Zigalova (2003). The Laboratory Manual for the Photosynthesis. Academia, Moscow. 256 стр. (in Russian).

Gomez, K. A. and A. A. Gomez (1984). Statistical Procedures for Agricultural Research, $2^{\text {nd }}$ ed., John Wiley and Sons., Inc. New York.

Habashy, N. R. and L.M. Aly (2005). Effect of organic growth promoting substances as humic acids and indol acetic acid on Wheat crop with special reference to some chemical composition. Minufiya Journal of Agricultural Research, 30:1607-1624.

Ismail, E. E. M., R. M. Galal and M. E. Mahseb (2017). Effect of some Potassium sources on productivity and quality of Pea under conditions of saline soil. Journal Plant Production, Mansoura University, 8 (12): 1323 1328.

Jackson, M. L. (1973). " Soil Chemical Analysis". Prentice Hall of Indian Private Limited, Dew Delhi. India.

Kaya, M., M. Atak , K.M. Khawar, C.Y. Ciftci and S. Ozcan (2005). Effect of pre-sowing seed treatment with zink and foliar spray humic acids on field of Common bean (Phaseolus vulgaris L.). Int. Journal Agriculture Biological, 7(6): 875-878.

Khan, A., A. Gurmani, M. Z. Khan, F. Hussain, M. E. Akhtar and S. Khan (2012). Effect of humic acid on the growth, yield, nutrient composition, photosynthetic pigment and total sugar contents of Peas (Pisum 
sativum L). Journal of the Chemical Society of Pakistan, 1: 1-7.

Kravchenko, I., A. Kizilova , L. Titova and G. Iutinskaya (2013). Effect of microbial fertilizers on rhizospheric bacterial diversity and yield response of Soybean plants. Agriculture Science Developments, 2 (12): 120125.

Malakooti, M.J. (2000). Sustainable Agriculture and Yield Increment by Optimum Fertilizer Utilization in Iran. 2nd edition. Agricultural Extension Publications, Iran.

Mertens, D. (2005a). A.O.A.C. Official method 922.02. plants preparation of laboratory sample. Official Methods of Analysis, $18^{\text {th }}$ ed. North Frederick Avenue, Gaitherburg, Maryland, 1-2 pp.

Mertens, D. (2005b). A.O.A.C. Official method 975.03. Metal in plants and pet foods. Official Methods of Analysis, $18^{\text {th }}$ ed. North Frederick Avenue, Gaitherburg, Maryland, 3-4 pp.

Nassar, K. E. and L. A. Abd EL-Rahman (2015). Impact of compost and methods of potasium humate application on Wheat. Minufiya Journal of Agriculture Research, 40 (5): 1377-1385.

Nassar, K.E. and K.M. Ismail (1999). Effect of ascorbic acid and phosphorus application on Lupin yield (Lupinus termis L.) grown on sandy soil. Egypt Journal of Applied Sciences, 14 (10): 357-368.

Rafla, H. H. (2012). Effect of humic acid and macronutrients on growth,yield and chemical composition of Faba bean (Vicia faba L.). Egypt Journal of Applied Sciences, 27: 927-944.

Rai, S. N. and V. D. Mudgal (1988). Synergistic effect of sodium hydroxide and steam pressure treatment on compositional and fiber utilization of Wheat straw. Biological waster, 24: 105-114.
Shafeek, M. R., Y. I. Helmy, N. M. Omer and F. A. Rizk (2013). Effect of foliar fertilizer with nutritional compound and humic acid on growth and yield of Broad bean plants under sandy soil conditions. Journal of Applied Sciences Research, 9(6) : 3674-3680.

Shumaila, G. and M. Safdar (2009). Proximate Composition and Mineral Analysis of Cinnamon. Pakistan Journal of Nutrition, 8 (9) : 1456-1460.

Tsvetkova, G.E. and G.I. Georgiev (2007). Changes in phosphate fractions extracted from different organs of phosphorus starved nitrogen fixing Pea plants. Journal Plant Nutrition, 30: 2129-2140.

USDA, (2014) . "Keys to Soil Taxonomy" . $12^{\text {th }}$ Edition, United States Department of Agriculture, Natural Resources Conservation Service, New York, USA.

Verlindern, G., B. Pycke, j. Mertens, F. Debersaques, K. Verheyen, G. Baert, J. Bries and G. H. saert (2009). Application of humic substances results in consistent increases in crop yield and nutrient uptake. Journal of Plant Nutrition 32:1407-1426.

Wang, X.G., X.H. Zhao, C.J. Jiang, C.H. Li, S. Cong , Y.Q. Chen, H. Q. Yu and C.Y. Wang (2015). Effects of potassium deficiency on photosynthesis and photoprotection mechanisms in Soybean (Glycine max (L.) Merr.). Journal of Integrative Agriculture, 14(5): 856-863.

Yadav, H., M. A. Shekh, S.S. Takar and B.S. Kherawat (2013). Effect of phosphorus and sulphur on content, uptake and quality summer Soybean. International Journal of Agricultural Science, 9: 91-94.

Yousif, S. H., K. H. Yousif and S. M. Salih (2019). Effect of bread yeast and humic acid on growth and yield traits on Broad bean (Vicia faba L.). 
K. E. M. Nassar, et al.,

Journal of University of Duhok., 22 (1):

98-106.

تأثير بعض طرق إضافة هيومات البوتاسيوم والتسميد المعدني الآزوتي والفوسفاتي على المحصول الكمي والنوعى لفول الصويا

كرم السيد محمد نصار، هيام عبد الفتاح الشابورى، أمانى السيد السنباطى

قسم خصوية الأراضي وتغذية النبات - معهز بحوث الاراضى والمياه والبيئة - مركز البحوث الزراعية - جيزة - مصر

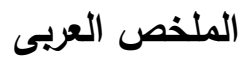

أجريت تجريتان حقليتان في قرية جديلة - مركز المنصورة - محافظة الدقهلية فى المواسم الصيفية لعامي

2017 ، 2018 بغرض دراسة التأثير الفردي لثلاث طرق لإضافة هيومات البوتاسيوم (10 \% K2O

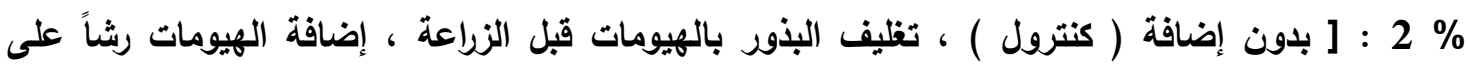

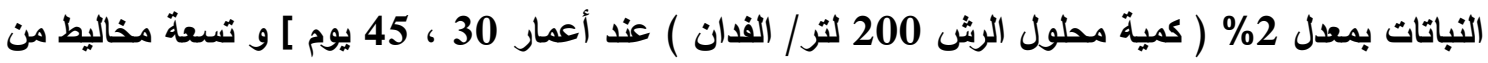
الأسمدة النيتروجينية والفوسفاتية المعدنية والتى تمثل المستويات المختلفة من عنصري النيتروجين والفوسفور

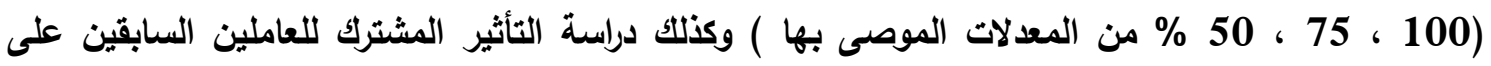
صبغات التمثيل الضوئي ، النمو ، المحصول الكمي لبذور فول الصويا والقش وكذا جودة البذور (محتواها الغذائي والحيوي).. لذا صممت التجريتان بنظام القطع المنشقة مرة واحدة فى ثلاث مكريات حيث خصصت القطع الرئيسية لطرق إضافة هيومات البوتاسيوم الثلاث بينما توزعت المخاليط التسع للأسمدة المعدنية عشوائياً فى القطع الفرعية .

وقد أثارت نتائج البحث لأهم النقاط الأتية : 1 - أدت إضافة هيومات البوتاسيوم بصفة عامة إلى زيادة محتوى الأوراق من صبغات التمثيل الضوئي ، ومقاييس النمو ، ومحصولى البذور والقش لنباتات فول الصويا فضلاً عن تحسين المحتوى الغذائي التئي

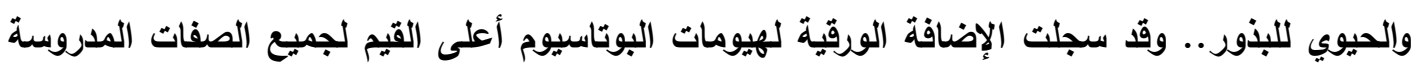

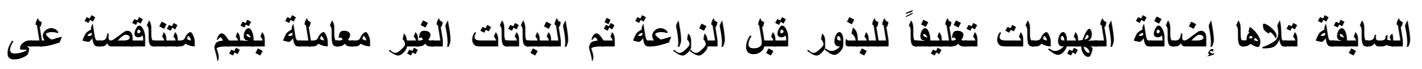
التوالي.

2 - تناقصت قيم جميع الصفات المدروسة والسابق الإشارة إليها بانخفاض مستويات النيتروجين أوالفوسفور أو

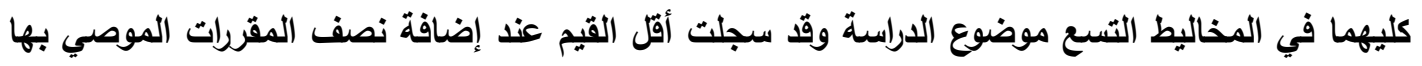
من سمادي كلا العنصرين أي مع المعاملة (50 \% ميتروجين + 50 \% م فوسفور) بينما تحققت أعلى

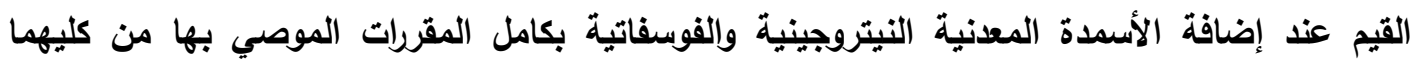

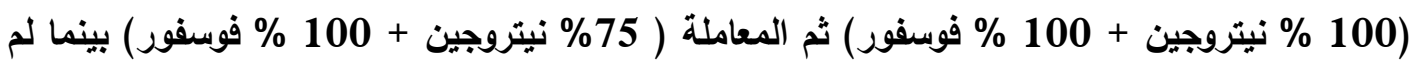
تكن هناك فروق معنوية بين هاتين المعاملتين السابقتين. 
3- سجلت إضافة هيومات البوتاسيوم والأسمدة المعدنية معاُ زيادات ملحوظة في جميع المقاييس المدروسة

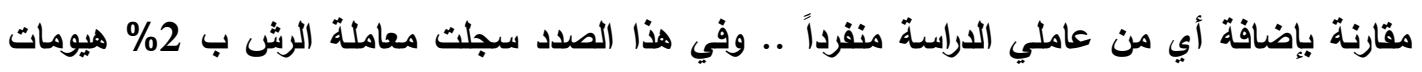

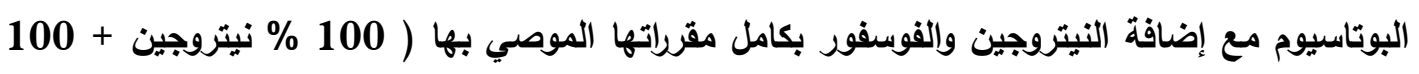
\% فوسفور) أعلى القيم ويدون وجود فرق معنوي بينها ومعاملة الرش بالهيومات وإضافة النيتروجين

$$
\text { والفوسفور بمعدلات (75\% + 100\%) من مقرراتهما الموصي بها على التوالي. }
$$

ومن ثم يمكن القول أن الرش الورقي لنباتات فول الصويا بمحلول هيومات البوتاسيوم بتركيز 25\% عند

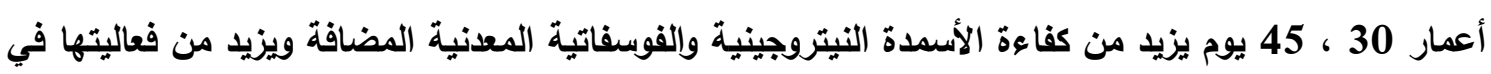

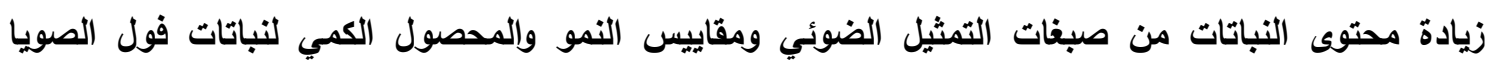
وتحسين جودته فضلاً عن توفير 25\% من إحتياجاته من التسميد الأزوتي. 
K. E. M. Nassar, et al.,

أسماء السادة المحكمين

أ.د/ رمضان إسماعيل كنانسى معهد بحوث الأراضى والمياه - مركز البحوث الزراعة

أ.د/ صلاح عبدالمجيد رضوان كلية الزراعة - جامعة المنوفية 